\title{
Knowledge about COVID-19 among university students before the implementation of the enhanced community quarantine in Philippines
}

\author{
Jomell M. Santiago ${ }^{1}$, Rita L. Cajucom ${ }^{2}$ \\ ${ }^{1}$ Faculty of College of Education, Nueva Ecija University of Science and Technology San Isidro Campus, Philippines \\ ${ }^{2}$ Laboratory High School, Nueva Ecija University of Science and Technology San Isidro Campus, Philippines
}

\begin{tabular}{l} 
Article Info \\
\hline Article history: \\
Received Jun 6, 2020 \\
Revised Aug 23, 2020 \\
Accepted Sep 15, 2020 \\
\hline
\end{tabular}

Keywords:

Coronavirus disease

COVID-19

Enhanced community

quarantine

Knowledge

\begin{abstract}
The purpose of this study was to determine the knowledge of the students about Coronavirus Disease-2019 (COVID-19) before the Philippines government implements the enhanced community quarantine in Luzon. A descriptive research design was conducted among the students of Nueva Ecija University of Science and Technology, San Isidro Campus. The sample size was computed by using the Epi-Info version 2000 Computer Programme. Questionnaire was used to collect data that was composed of the profile, questions regarding their knowledge about COVID-19 and their source of knowledge. Permission to conduct and informed consent was obtained before the respondent answer the questionnaire. Data were analyzed using various statistical tools. Majority of the respondents had an average and good knowledge while sex was the only variable that differs significantly in their knowledge about COVID-19. Social media and seminars in the school were among their primary source of knowledge. It is concluded that students' knowledge about COVID-19 was sufficient. However, the absence of vaccines against COVID-19, prevention and control of the disease was the only way to fight it which requires organizing health education campaigns in different communities to disseminate more information on how everybody can effectively deal with this pandemic.
\end{abstract}

This is an open access article under the CC BY-SA license.

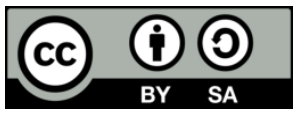

Corresponding Author:

Jomell M. Santiago,

Faculty of College of Education,

Nueva Ecija University of Science and Technology San Isidro Campus,

3106 Poblacion, San Isidro, Nueva Ecija, Philippines.

Email: jomellsantiago8854@gmail.com

\section{INTRODUCTION}

Coronaviruses are a large family of viruses that are commonly found in the community and can be transmitted through birds and mammals [1]. COVID-19 caused by the new coronavirus is a new disease, that has not previously been seen in humans and is not the same as the coronaviruses that commonly circulate among humans and cause mild illness, like the common cold. The virus that causes COVID-19 was formerly known as "2019-nCoV or 2019 novel coronavirus" and was then called as syndrome coronavirus 2 (SARS- 
CoV-2) by the International Committee on Taxonomy of Viruses (ICTV) [2]. It was believed that the infections originate in Wuhan, one of the major transport hubs in China [3]. There is a probability thatthe virus that causes COVID-19 come out from an animal source [4]. The first case was uncovered by Chinese state media on the $31^{\text {st }}$ of December after 44 individuals in Wuhan were confirmed to be infected. It was first referred to as "mystery viral pneumonia," as infected people have flu-like symptoms. Strict screening measures for people moving out in the city were implemented by Wuhan officials [5]. The first mortality due to COVID-19 was a 61-year-old man expose to the seafood market [6]. As of January 2020, there were confirmed cases in all regions of China. COVID-19 also extended in other countries which include South Korea, Japan, the Philippines, and the US, with most cases confirmed had traveled in Wuhan, China [7].

On January 30, 2020, the International Health Regulations Emergency Committee of the World Health Organization declared the outbreak a "Public Health Emergency of International Concern" [6, 8]. On February 2, 2020, in the middle of the continuous increase of death in China, the first death outside China was reported in the Philippines which is a Chinese man from Wuhan. On the eleventh day of March 2020, WHO characterized COVID-19 as a pandemic where 114 countries around the world were affected. Pandemic is an outbreak of disease globally. It happens when a new virus emerges to infect people and can spread between people sustainably [8].

As of March 11, 2020, more than a hundred thousand COVID-19 cases were recorded and more than four thousand deaths, according to the Johns Hopkins Whiting School of Engineering's Centers for Systems Science and Engineering. Italy, which has seen its outbreak worsen in recent days, now has 10,149 cases [9]. The Philippines reported 3 new confirmed cases on March 12, making the total number of infected to 52. Of the 52 patients-two deaths were recorded: a 44-year-old Chinese man who traveled to the Philippines from Wuhan, China, and a 67-year-old Filipina woman with no travel history outside the country and the Philippines' first local fatality due to COVID-19 [10]. Because of the pandemic, the Philippines imposes the travel ban to all countries which have localized transmission of the viral disease. The entry of people from countries with local transmissions will be prohibited, except for Filipino citizens, their foreign spouse, and children, permanent residents, and holders of diplomatic visas. The World Health Organization identified that 65 countries, including the Philippines, South Korea, Japan, and the US, have local transmissions of the viral disease [11].

COVID-19 patients may have mild to severe respiratory illness with symptoms such as fever, cough and shortness of breath. As of now, there is no specific antiviral treatment or vaccine to protect against COVID-19. The best way to prevent infection is to avoid being exposed to the virus which can be done by avoiding close contact with people who are sick. Washing hands often with soap and water for at least 20 seconds and the use of an alcohol-based hand sanitizer can also prevent an individual to be exposed to the virus. To keep someone who is exposed and suspected to have COVID-19 from spreading it to others, he/she should stay home when sick, cover cough or sneeze with a tissue, then throw the tissue in the trash and clean and disinfect frequently touched objects and surfaces [4].

The battle against the COVID-19 pandemic is continuing in the Philippines. To beat this pandemic, the participation of all individuals is essential and their knowledge is one that is affected [12]. The SARS outbreak in 2003 taught people around the world that knowledge towards infectious diseases has something to do with their emotions which can further complicate attempts to prevent the spread of the disease [13]. Also, [14] states that face-to-face health education on knowledge for a certain infectious disease can improve their awareness and gives a positive effect on their health education towards the control and prevention of the said diseases. Since face-to-face discussion is not an option nowadays, social media become an alternative way of educating the public since important information are readily available, especially in times when timely information is critical, e.g., during health crisis like COVID-19 pandemic [15]. With this, health authorities are maximizing this opportunity to disseminate timely and critical information especially during the time of pandemic the whole world is dealing with [16, 17].

Knowledge regarding this pandemic is associated with positive attitudes and applicable practices suggesting that health education programs aimed at improving COVID-19 knowledge help encourage optimistic attitudes and maintain safe practices [18]. However, [19] state that better knowledge does not necessarily lead to better practice. Thus, everyone must gain the best knowledge and information as possible to efficiently face this pandemic. When every individual was equipped with sufficient knowledge about COVID-19, the battle against this unseen enemy will soon be over. Therefore, to determine if everyone especially those whose age was below 20 and were considered vulnerable to this pandemic, it is necessary to assess their knowledge about COVID-19. Evaluating their knowledge about COVID-19 will help the health authorities to address common concerns related to COVID-19. Thru the collective effort and participation of everyone, the fight in this contagion will soon be over. This study specifically aimed to determine the knowledge of the students of Nueva Ecija University of Science and Technology San Isidro Campus about COVID-19, the difference among their various socio-demographic factors and their source of knowledge. Findings from this study would provide useful baseline information about the present knowledge of the respondents about COVID- 19.

Int. J. Public Health Sci, Vol. 9, No. 4, December 2020: $421-428$ 


\section{RESEARCH METHOD}

Descriptive quantitative research design was used to assess the knowledge of the students before the implementation of the enhanced community quarantine regarding COVID-19 and was conducted in Nueva Ecija University of Science and Technology, San Isidro Campus, which is located at the province of Nueva Ecija, at the heart of municipal of San Isidro. It was initiated in January 2020 and completed in March 2020 before the Philippine government put the entire Luzon under Enhanced Community Quarantine due to the local transmission of the said disease. Epi-Info version 2000 Computer Programme was used to compute the sample size. An error of $2.5 \%$, a $5 \%$ level of significance, and a $95 \%$ confidence interval allowed indicate that a sample size of 500 subjects would be required to complete the objectives of our study. The target population was students of all programs and year level. Out of 500 respondents approached, only 481 participate and provided consent to participate in the study.

The questionnaire made by [20] for SARS and [21] for the Dengue virus was adapted for the study. The questionnaire was revised for content and wording following an extensive review of the literature published and expert opinions. The questionnaire was made up of three main parts: the first part consists of questions regarding socio-demographic status (sex, type of residence, highest educational attainment and occupation of parents and monthly income; the second part is about their knowledge about COVID-19 was comprised of the general knowledge, transmission, sign and symptoms and prevention of COVID-19. The last part was about the source of knowledge where the respondents obtained their information about COVID-19. Before the questionnaire was used in the main study, it was pre-tested among the students of the said campus which were not included in the final analysis. Cronbach's Alpha [22] was used to assess the reliability coefficient which is a measure of the internal consistency of the questionnaire. The result showed that Cronbach's Alpha coefficients were 0.96. The acceptable minimum value of reliability was 0.7 [23, 24]. During the distribution of the questionnaires, a certain precautionary measure such as social distancing, use of face mask, and disinfection was done. Permission was sought to the Campus Director and informed consent was given first before the respondent answer the questionnaire. Adequate time was given and voluntary participation was highlighted. The anonymity of the subjects and confidentiality of information was maintained and assured that the study will not harm the participants in any way.

All completed questionnaires were double-checked and verified for completeness and consistency. The data was then entered in Microsoft Excel and statistical packages for social sciences (SPSS). The responses to the knowledge questions were coded with one (1) for correct answers and zero (0) for incorrect and "do not know" answers, with a maximum of 10 points for each category and 40 overall. The response was defined as correct if it was valid. "Do not know (DNN)" responses are equivalent to wrong answers which is a conventional practice as responses either come from the least knowledgeable respondents or the vast majority of those saying "DNN" really do not know [25]. Treating "DNN" as a wrong answer appears reasonable and justifiable in the study although it is a conservative strategy [26]. In contrast, dropping "DNN" responses from the data set reduces the sample size, may introduce sample selection bias and result in a serious loss of information [26]. Hence, it was not excluded "DNN" in the analyses. Further, knowledge for each category and the overall knowledge of students was calculated in percent, and the level of knowledge was classified as Very Poor (<20\%), Poor (21-40\%), Average (41-60\%), Good (61-80\%), and Very Good (81-100\%) based on 20\% cut-off point. For instance, with a total of 40 questions for overall knowledge, a respondent obtaining scores between 40 and 32 was categorized as having very good knowledge, scores between 31 and 24 have good knowledge, scores between 23 and 16 have average knowledge, scores between 15 and 8 have poor knowledge and scores between 7 and 0 have very poor knowledge. For the 10 questions for each category, a respondent securing score between 10 and 9 were categorized as having very good knowledge, scores between 8 and 7 have good knowledge, scores between 6 and 5 have average knowledge, scores between 4 and 3 have poor knowledge and scores between 2 and 0 have very poor knowledge. For the socio-demographic profile, frequency and percentage were computed. Other statistical tools used were One-way Analysis of Variance (ANOVA) Single Factor and T-test for two sample assuming unequal variances to determine whether significant differences existed in their profile concerning their level of knowledge regarding COVID-19.

\section{RESULTS AND DISCUSSION}

\subsection{Socio-demographic profile of the respondents}

A total of 481 respondents were selected to participate in a study consisting of $270(56.10 \%)$ females and $211(43.90 \%)$ males. Many of them or $438(91.10 \%)$ were residents of a rural area and their father or $224(46.6 \%)$ and mother or $218(45.30 \%)$ were High School graduates. Many of the occupations of their father or $185(38.5 \%)$ and mother or $173(36 \%)$ were unskilled. The majority of them or 191 $(39.70 \%)$ had a family monthly income below P7890.00 as shown in Table 1. 
Table 1. Socio-demographic profile of the respondents

\begin{tabular}{|c|c|c|}
\hline Socio-demographic profile & Frequency (f) & Percentage $(\%)$ \\
\hline \multicolumn{3}{|l|}{ Sex } \\
\hline Male & 211 & 43.90 \\
\hline Female & 270 & 56.10 \\
\hline \multicolumn{3}{|l|}{ Residence } \\
\hline Rural & 438 & 91.10 \\
\hline Urban & 43 & 8.90 \\
\hline \multicolumn{3}{|l|}{ Educational attainment of father } \\
\hline College & 174 & 36.20 \\
\hline High school & 224 & 46.60 \\
\hline Elementary & 83 & 17.30 \\
\hline \multicolumn{3}{|l|}{ Educational attainment of mother } \\
\hline College & 180 & 37.40 \\
\hline High school & 218 & 45.30 \\
\hline Elementary & 83 & 17.30 \\
\hline \multicolumn{3}{|l|}{ Occupation of father } \\
\hline Professional & 62 & 12.90 \\
\hline Skilled & 183 & 38.00 \\
\hline Unskilled & 185 & 38.50 \\
\hline Unemployed & 51 & 10.60 \\
\hline \multicolumn{3}{|l|}{ Occupation of mother } \\
\hline Professional & 86 & 17.90 \\
\hline Skilled & 86 & 17.90 \\
\hline Unskilled & 173 & 36.00 \\
\hline Housewife & 136 & 38.30 \\
\hline \multicolumn{3}{|l|}{ Monthly gross family income } \\
\hline $\mathrm{P} 7,890$ and below & 191 & 39.70 \\
\hline P7,891-P 15,780 & 144 & 29.90 \\
\hline $\mathrm{P} 15,781-\mathrm{P} 31,560$ & 120 & 24.90 \\
\hline $\mathrm{P} 31,561-\mathrm{P} 78,900$ & 15 & 3.10 \\
\hline P P78,900 and above & 11 & 2.30 \\
\hline
\end{tabular}

\subsection{Knowledge of the respondents regarding COVID-19}

Results showed that very good knowledge was found in $4(0.83 \%)$ respondents, good in 111 $(23.08 \%)$, average in $307(63.83 \%)$, poor in $49(10.19 \%)$, and $9(0.02 \%)$ respondents had very poor knowledge regarding COVID-19. The present study reveals that the majority of the respondents had average and good knowledge about COVID-19. According to [27], most of the respondents' level of knowledge about COVID-19 was between averages to good knowledge because their awareness as social responses simultaneously appeared as an epidemic develops. Raising the level of knowledge in all aspects of diseases like COVID-19 which includes its origin, transmission, signs and symptoms and prevention could not only help the general population protect themselves, but also promote those suspected from being infected to seek medical help early and treat more completely as shown in Table 2 [28].

Table 2. Knowledge scores of the respondents regarding COVID-19

\begin{tabular}{cccc}
\hline Socio-demographic profile & Criteria & Frequency (f) & Percentage (\%) \\
\hline Very good & $32-40$ & 4 & 0.83 \\
Good & $24-31$ & 111 & 23.08 \\
Average & $16-23$ & 307 & 63.83 \\
Poor & $8-15$ & 49 & 10.19 \\
Very poor & $0-7$ & 9 & 0.02 \\
\hline
\end{tabular}

\subsection{Knowledge of the respondents regarding COVID-19 in different category}

In terms of their mean score regarding their general knowledge about COVID-19, the result revealed that many or $388(80.80 \%)$ of them got the correct answer on item statement 1 "2019-nCOV belongs in a large family of viruses called coronavirus". However, only a quarter or $118(24.60 \%)$ of the respondents answered correctly the item statement 2 "2019-nCov is the same virus that causes Severe Acute Respiratory Syndrome". Most of them had a wrong answer because they mistakenly perceived that the pathogen that causes COVID-19 and SARS was the same as shown in Table 3.

Their knowledge about the transmission of COVID-19 showed that majority or $411(85.60 \%)$ of them got the correct answer on item statement 1 "COVID-19 can be transmitted from person to person, usually after close contact with an infected patient". However, most or $392(81.70 \%)$ of them got the wrong answer in statement 8 that companion animals or pets have been infected or have spread COVID-19" as shown in Table 4.

Int. J. Public Health Sci, Vol. 9, No. 4, December 2020: $421-428$ 
Their knowledge about the sign and symptoms of COVID-19 revealed that more than three parts or 365 (76\%) of the respondents got the correct answer on item statement 3 "Cough is one of the symptoms of COVID-19". Meanwhile, more than three parts or $361(75.20 \%)$ of the respondents got wrong answers in statement 10 "The sign and symptoms of COVID-19 will appear before the incubation period" as shown in Table 5.

Table 3. Mean scores of the respondents regarding their general knowledge about COVID-19

\begin{tabular}{|c|c|c|c|c|c|}
\hline \multirow[t]{2}{*}{ Item statements } & \multirow{2}{*}{$\begin{array}{c}\text { Mean score/ } \\
\text { S.D. }\end{array}$} & \multicolumn{2}{|c|}{$\begin{array}{l}\text { Correct } \\
\text { answer }\end{array}$} & \multicolumn{2}{|c|}{$\begin{array}{l}\text { Wrong } \\
\text { answer }\end{array}$} \\
\hline & & $\mathrm{F}$ & $\%$ & $\mathrm{~F}$ & $\%$ \\
\hline 1. 2019-nCOV belongs to a large family of viruses called coronavirus. & $0.81 \pm 0.39$ & 389 & 81.00 & 91 & 19.00 \\
\hline $\begin{array}{l}\text { 2. 2019-nCov is the same virus that causes Severe Acute Respiratory Syndrome or } \\
\text { (SARS-COV). }\end{array}$ & $0.25 \pm 0.43$ & 118 & 24.60 & 362 & 75.40 \\
\hline $\begin{array}{l}\text { 3. A novel coronavirus is a new strain of coronavirus and had not previous by detected } \\
\text { before the outbreak was reported in Wuhan, China in December } 2019 \text {. }\end{array}$ & $0.81 \pm 0.39$ & 388 & 80.80 & 92 & 19.20 \\
\hline $\begin{array}{l}\text { 4. It is safe to receive a package from China or any other place where the virus has } \\
\text { been identified. }\end{array}$ & $0.43 \pm 0.69$ & 194 & 40.50 & 286 & 59.50 \\
\hline 5. Infection with 2019-nCov can cause mild symptoms and can lead to pneumonia. & $0.63 \pm 0.48$ & 189 & 39.40 & 291 & 60.60 \\
\hline 6. Antibiotics are effective in treating COVID-19. & $0.39 \pm 0.49$ & 388 & 80.80 & 92 & 19.20 \\
\hline 7. COVID-19 can be more severe and fatal for some persons. & $0.61 \pm 0.49$ & 294 & 61.20 & 186 & 38.80 \\
\hline 8. The incubation period of 2019 -nCov could be up to 24 to 48 hours. & $0.39 \pm 0.49$ & 187 & 39.00 & 293 & 61.00 \\
\hline $\begin{array}{l}\text { 9. Preliminary information suggests that } 2019-\mathrm{nCov} \text { may survive a few hours or home } \\
\text { on surfaces. }\end{array}$ & $0.41 \pm 0.49$ & 195 & 40.60 & 285 & 59.40 \\
\hline 10. The new coronavirus was deliberately created or release by people. & $0.37 \pm 0.48$ & 176 & 36.70 & 304 & 63.30 \\
\hline
\end{tabular}

Legend: $\mathrm{f}=$ frequency, $\%=$ percentage, S.D. = standard deviation

Table 4. Mean scores of the respondents regarding their knowledge about the transmission of COVID-19

\begin{tabular}{|c|c|c|c|c|c|}
\hline \multirow{2}{*}{ Item statements } & \multirow{2}{*}{$\begin{array}{l}\text { Mean score/ } \\
\text { S.D. }\end{array}$} & \multicolumn{2}{|c|}{ Correct answer } & \multicolumn{2}{|c|}{ Wrong answer } \\
\hline & & $\mathrm{F}$ & $\%$ & f & $\%$ \\
\hline $\begin{array}{l}\text { 1. COVID-19 can be transmitted from person to person, usually after close contact } \\
\text { with an infected patient. }\end{array}$ & $0.86 \pm 0.35$ & 411 & 85.60 & 69 & 14.40 \\
\hline $\begin{array}{l}\text { 2.2019-nCov spread through respiratory droplets generated when a person cough or } \\
\text { sneeze. }\end{array}$ & $0.81 \pm 0.39$ & 389 & 81.00 & 91 & 19.00 \\
\hline $\begin{array}{l}\text { 3. People who have symptoms of COVID-19 are causing the majority of virus } \\
\text { spread. }\end{array}$ & $0.81 \pm 0.39$ & 390 & 81.20 & 90 & 18.80 \\
\hline 4. The consumption of undercooked animal products can transmit COVID-19. & $0.73 \pm 0.45$ & 348 & 72.50 & 132 & 27.50 \\
\hline 5. Health workers are at higher risk of getting infected by COVID-19. & $0.63 \pm 0.48$ & 324 & 67.80 & 154 & 32.20 \\
\hline $\begin{array}{l}\text { 6. Someone who has been released from COVID-19 quarantine is still considered a } \\
\text { risk for spreading the virus to others. }\end{array}$ & $0.29 \pm 0.45$ & 137 & 28.50 & 343 & 71.50 \\
\hline $7.2019-\mathrm{nCov}$ is an airborne virus that can spread through the air. & $0.31 \pm 0.46$ & 148 & 30.80 & 332 & 69.20 \\
\hline $\begin{array}{l}\text { 8. At present, there is evidence that companion animals or pets such as cats and } \\
\text { dogs have been infected or have spread COVID- } 19 \text {. }\end{array}$ & $0.18 \pm 0.39$ & 88 & 18.30 & 392 & 81.70 \\
\hline $\begin{array}{l}\text { 9. Covering your mouth and nose when coughing and sneezing does not prevent the } \\
\text { spread of the virus. }\end{array}$ & $0.33 \pm 0.47$ & 156 & 32.50 & 324 & 67.50 \\
\hline $\begin{array}{l}\text { 10. A simple cough or sneeze } n \text { to your hands is not enough to contaminate objects } \\
\text { or people that you touch. }\end{array}$ & $0.35 \pm 0.48$ & 166 & 34.60 & 314 & 65.40 \\
\hline
\end{tabular}

Legend: $\mathrm{f}=$ frequency, $\%$ = percentage, S.D. = standard deviation

Table 5. Mean scores of the respondents regarding their knowledge about the sign and symptom of COVID-19

\begin{tabular}{|c|c|c|c|c|c|}
\hline \multirow{2}{*}{ Item statements } & \multirow{2}{*}{$\begin{array}{c}\text { Mean score/ } \\
\text { S.D. }\end{array}$} & \multicolumn{2}{|c|}{ Correct answer } & \multicolumn{2}{|c|}{ Wrong answer } \\
\hline & & $\mathrm{F}$ & $\%$ & $\mathrm{f}$ & $\%$ \\
\hline 1. Fever is one of the symptoms of COVID- 19. & $0.75 \pm 0.43$ & 359 & 74.90 & 121 & 25.10 \\
\hline 2. Shortness or difficulties in breathing is one of the symptoms of COVID-19. & $0.54 \pm 0.50$ & 262 & 54.50 & 218 & 45.50 \\
\hline 3. Cough is one of the symptoms of COVID- 19 . & $0.76 \pm 0.43$ & 365 & 76.00 & 115 & 24.00 \\
\hline 4. Sore throat is one of the symptoms of COVID-19. & $0.68 \pm 0.47$ & 327 & 68.30 & 152 & 31.70 \\
\hline $\begin{array}{l}\text { 5. People who show imaging features of coronavirus on } \mathrm{x} \text {-ray or CT scan are none } \\
\text { likely to be infected. }\end{array}$ & $0.32 \pm 0.47$ & 155 & 32.20 & 325 & 67.80 \\
\hline $\begin{array}{l}\text { 6. Travelers from places where the outbreak locations are more likely to have the } \\
\text { infection. }\end{array}$ & $0.64 \pm 0.48$ & 305 & 63.40 & 174 & 36.30 \\
\hline $\begin{array}{l}\text { 7. Confirmatory tests for COVID-19 are not required if the patient has flu-like } \\
\text { symptoms. }\end{array}$ & $0.38 \pm 0.48$ & 180 & 37.50 & 300 & 62.50 \\
\hline 8. The symptoms may appear 48 hours after exposure. & $0.26 \pm 0.44$ & 127 & 26.50 & 353 & 73.50 \\
\hline 9. Muscle pain is not a symptom of COVID- 19 . & $0.32 \pm 0.47$ & 153 & 31.90 & 327 & 68.10 \\
\hline 10. COVID-19's sign and symptoms will appear before the incubation period. & $0.25 \pm 0.43$ & 119 & 24.80 & 361 & 75.20 \\
\hline
\end{tabular}

Their knowledge about the prevention of COVID-19 showed that most or $384(37.70 \%)$ of the respondents know that wearing a face mask can help limit the spread of COVID-19. Statements which includes the sign and symptoms of COVID-19 will appear before the incubation period and using essential

Knowledge about COVID-19 among university students before the implementation... (Jomell M. Santiago) 
oils, water, ethanol or other substances can prevent one of having COVID-19 were not answered by the respondents correctly maybe due to lack of information. Everyone must know all the facts of this pandemic. According to [29], it is important to provide health education and create awareness during such situations for effective prevention of the spread of disease as shown in Table 6 .

Table 6. Mean scores of the respondents regarding their knowledge about the prevention of COVID-19

\begin{tabular}{|c|c|c|c|c|c|}
\hline \multirow{2}{*}{ Item statements } & \multirow{2}{*}{$\begin{array}{l}\text { Mean score/ } \\
\text { S.D. }\end{array}$} & \multicolumn{2}{|c|}{ Correct answer } & \multicolumn{2}{|c|}{ Wrong answer } \\
\hline & & $\mathrm{F}$ & $\%$ & f & $\%$ \\
\hline $\begin{array}{l}\text { 1. Washing hands frequently with soap and water eliminates the virus if it is on } \\
\text { your hands. }\end{array}$ & $0.76 \pm 0.42$ & 367 & 76.50 & 113 & 23.50 \\
\hline 2. Maintain at least 1-meter (3-feet) distance between yourself and other people. & $0.74 \pm 0.44$ & 354 & 73.70 & 126 & 26.30 \\
\hline 3. Wearing a medical mask can help limit the spread of COVID-19. & $0.80 \pm 0.40$ & 384 & 80.20 & 95 & 19.80 \\
\hline 4. If you have a fever, cough, and difficulty breathing, seek medical care early. & $0.77 \pm 0.42$ & 371 & 77.30 & 109 & 22.70 \\
\hline 5. Clean and disinfect frequently touched objects and surfaces. & $0.74 \pm 0.44$ & 355 & 74.00 & 125 & 26.00 \\
\hline 6. Using medical mask alone guaranteed to stop infections. & $0.34 \pm 0.47$ & 161 & 33.50 & 319 & 66.50 \\
\hline 7. Taking acetic acid or steroids can protect you from having COVID-19. & $0.34 \pm 0.47$ & 163 & 33.70 & 317 & 66.30 \\
\hline $\begin{array}{l}\text { 8. Using essential oils, water, ethanol or other substances can prevent you from } \\
\text { having COVID-19. }\end{array}$ & $0.28 \pm 0.49$ & 133 & 27.70 & 347 & 72.30 \\
\hline 9. Taking traditional herbal tea can help prevent COVID-19. & $0.29 \pm 0.45$ & 139 & 29.00 & 341 & 71.00 \\
\hline 10. Do not use alcohol-based because it cannot eliminate the virus in your hands. & $0.45 \pm 0.50$ & 215 & 44.90 & 264 & 55.10 \\
\hline
\end{tabular}

\subsection{Difference between the profile of the respondents to their knowledge about COVID-19}

Results revealed that males had a mean score of $21.42 \pm 5.35$ which was higher than the mean score of females which was $20.19 \pm 4.97$. The difference between the sex (p-value $=0.006$ ) to their overall knowledge about COVID-19 was significant. The study of $[30,31]$ was in contrast to the result of the study since males had a higher mean score than females. In the study of [30] about gender differences in health literacy about tuberculosis (TB) which is also an infectious disease like COVID-19, [30] noted that females were more aware than males. Gender is a significant factor affecting infectious disease prevention behavior of students. One probable reason for their difference was that female was more delicate than male and giving more attention to personal health care [31]. Also, [32] noted that men often are unwilling and lack the motivation to engage with health-related information both in times of stressful life events and in everyday life. Also, women gain more information and may spend more time watching TV programs [33]. The other variable had no significant difference in their overall knowledge about COVID-19 as shown in Table 7.

Table 7. Difference between the profile of the respondents and their knowledge scores regarding COVID-19

\begin{tabular}{lcc}
\hline Socio-demographic profile & Knowledge scores mean \pm S.D. & Percentage(\%) \\
\hline Sex & & \\
Male & $21.42 \pm 5.35$ & $0.0061^{*}$ \\
$\quad$ Female & $20.19 \pm 4.97$ & \\
Residence & $20.81 \pm 4.82$ & 0.2047 \\
$\quad$ Rural & $19.84 \pm 5.39$ & \\
$\quad$ Urban & $20.18 \pm 4.93$ & \\
Educational attainment of father & $20.93 \pm 4.40$ & 0.5060 \\
$\quad$ College & $20.72 \pm 5.38$ & \\
High school & & \\
Elementary & $20.65 \pm 4.87$ & \\
Educational attainment of mother & $20.33 \pm 4.61$ & 0.1904 \\
$\quad$ College & $21.22 \pm 5.16$ & \\
High school & & \\
Elementary & $21.15 \pm 4.54$ & \\
Occupation of father & $21.07 \pm 4.71$ & \\
$\quad$ Professional & $20.38 \pm 5.17$ & \\
Skilled & $20.24 \pm 4.76$ & \\
Unskilled & & \\
Unemployed & $21.32 \pm 4.03$ & \\
Occupation of mother & $20.62 \pm 4.48$ & \\
$\quad$ Professional & $20.10 \pm 5.36$ & \\
Skilled & $21.20 \pm 4.91$ & \\
Unskilled & & \\
Housewife & $20.30 \pm 4.84$ & \\
Monthly gross family income & $20.94 \pm 4.97$ & \\
P7,890 and below & $21.22 \pm 5.05$ & \\
P7,891-P 15,780 & $19.53 \pm 3.80$ & \\
P15,781-P31,560 & $21.45 \pm 3.27$ & \\
P31,561-P78,900 & & \\
P P78,900 and above & & \\
\hline
\end{tabular}

Int. J. Public Health Sci, Vol. 9, No. 4, December 2020: 421 - 428 
In terms of their source of knowledge about COVID-19, the result showed that the topmost source or $437(91 \%)$ of them get information from the seminar from the school and social media. The least source of knowledge was from observation and personal experience. Today, social media such as Twitter, Facebook and Instagram, have become primary sources of information [15]. That the roles of social media played during a pandemic were as a source of information and can influence public response to the outbreak [34]. Moreover, majority of the available information available was in the English language making it more comprehensible for the respondents since they learn better when the medium of language used was English [35]. Besides, [36] state that conducting school health education like seminars in the school can effectively slow the spread of infectious disease and provides students with right knowledge and behavior toward infectious diseases like COVID-19 as shown in Table 8.

Table 8. Source of knowledge of the respondents about COVID-19

\begin{tabular}{lcc}
\hline \multicolumn{1}{c}{ Item statements } & Yes & Percent \\
\hline 1. from news and reports from the television & 425 & 88.50 \\
2. from radio & 420 & 87.50 \\
3. awareness campaign in your community & 431 & 89.80 \\
4. from your teacher & 422 & 87.90 \\
5. from your relatives & 424 & 88.30 \\
6. from observation and personal experiences & 413 & 86.00 \\
7. from newspaper & 427 & 87.00 \\
8. from seminar awareness in your school & 437 & 91.00 \\
9. from social media & 437 & 91.00 \\
10. from your friends & 431 & 89.80 \\
\hline
\end{tabular}

\section{CONCLUSION}

It was concluded that the majority of the respondents had average and good knowledge regarding COVID-19 and the only socio-demographic profile that differ significantly in their overall knowledge was sex. Last, social media and seminars in the school were among the primary source of knowledge or information about COVID-19. In the absence of an effective vaccine for COVID-19, the prevention and control of the disease mainly depended upon the epidemiological surveillance and implementation of effective health protocol measures such as social distancing, wearing of face mask, and frequent washing of hands with water and soap. Therefore, organizing health education campaigns in different communities is necessary to disseminate more information on how everybody can effectively deal with this pandemic.

\section{ACKNOWLEDGEMENTS}

The researcher wants to thank the following: First, to the campus Director of San Isidro, Dr. Ma. Teresita C. Vega, for her support in the conduct of this study. Second, to all of the students who participate and help the researcher for the completion of this study especially to Frenzy Peñafiel and Katrina Joy Palon.

\section{REFERENCES}

[1] Schoeman D and Fielding BC, "Coronavirus envelope protein: Current knowledge," Virol J., vol. 16, no. 1, p. 69, 2019.

[2] Cascella M., Rajnik M., Cuomo A., Dulebohn SC and Di Napoli R: Features, Evaluation and Treatment Coronavirus (COVID-19). StatPearls Publishing, Treasure Island, FL; 2020. [Online]. Available: https://www.ncbi.nlm.nih.gov/books/NBK554776/

[3] Carlos WG, Dela Cruz CS, Cao B, Pasnick S, and Jamil S, "Novel Wuhan (2019-nCoV) Coronavirus," Am J Respir Crit Care Med., vol. 201, no. 4, pp. 7-8, 2020.

[4] Centers for Disease Control and Prevention, March 12, 2020. [Online]. Available: https://www.cdc.gov/coronavirus/2019-nCoV/summary.html\#anchor_1580079137454

[5] Novel coronavirus or 2019-nCoV: What we know so far. (2020, January 21). [Online]. Retrieved from https://www.rappler.com/newsbreak/iq/249868-novel-coronavirus-what-we-know-so-far

[6] WHO, "Pneumonia of unknown cause-China," 2020. [Online]. Retrieved from https://www.who.int/csr/don/05january-2020-pneumonia-of-unkown-cause-china/en/

[7] How does COVID-19 compare to SARS and MERS? 2020. [Online]. Available: https://www.rappler.com/newsbreak/iq/252188-comparison-covid-19-sars-mers

[8] Coronavirus disease (COVID-19)-events as they happen. (n.d.) 2019. [Online]. Available: https://www.who.int/emergencies/diseases/novel-coronavirus-2019/events-as-they-happen

[9] Lee, J., COVID-19 case tally: 124,578 cases, 4,584 deaths, 2020. [Online]. Available: https://www.marketwatch.com/story/covid-19-case-tally-120944-cases-4365-deaths-2020-03-11 
[10] Novel coronavirus cases in the Philippines now at 52. 2020. [Online]. Available: https://www.rappler.com/nation/254279-doh-confirms-new-cases-coronavirus-philippines-march-12-2020

[11] CNN Philippines Staff, 2020. [Online]. Available: https://www.cnnphilippines.com/news/2020/3/12/Philippinesexpands-travel-ban-to-all-countries-with-local-COVID-19-transmission.html

[12] Ajilore K., Atakiti I., Onyenankey K., "College students' knowledge, attitudes and adherence to public service announcements on Ebola in Nigeria: Suggestions for improving future Ebola prevention education programmes." Health Education Journal, vol. 76, no. 6, pp. 648-66076, 2017.

[13] Tao N., "An analysis on reasons of SARS-induced psychological panic among students," Journal of Anhui Institute of Education, vol. 21, pp. 78-9, 2003.

[14] X. L. Yue, "Effect of health education in face-to-face type on pupils' understanding of knowledge of mumps," Qilu Nurse Journal, vol. 21, no. 5, pp. 32-33, 2015.

[15] Chew C., Eysenbach G., "Pandemics in the age of Twitter: content analysis of Tweets during the 2009 H1N1 outbreak," PLoS One, vol. 5, no. 11, e14118, 2010.

[16] Thomas TL, Schrock C and Friedman DB., "Providing Health Consumers with Emergency Information: A Systematic Review of Research Examining Social Media Use During Public Crises," J Consum Health Internet. vol. 20, no. 1-2, pp. 19-40, 2016.

[17] Chou WS, Hunt YM, Beckjord EB, Moser RP, Hesse BW. Social media use in the United States: implications for health communication, J Med Internet Res., vol. 11, no. 4, p. e48. 2009

[18] Zhong, B., Luo, W., Li, H., Zhang, Q., Liu, X., Li, W., \& Li, Y., "Knowledge, attitudes, and practices towards COVID-19 among Chinese residents during the rapid rise period of the COVID-19 outbreak: A quick online crosssectional survey,” International Journal of Biological Sciences, vol. 16, no. 10, pp. 1745-1752. 2020.

[19] Shuaib, F., Todd, D., Campbell-Stennett, D., Ehiri, J., \& Jolly, P. E., "Knowledge, attitudes and practices regarding dengue infection in Westmoreland, Jamaica. The West Indian Medical Journal, Volume 59, Issue 2, pp. 139-146, 2010.

[20] Tayyaba S., Muhammad I Q., "Sagacity about SARS among University Students," Open Acc J Oncol Med., vol. 2 , no. 4, pp. 199-201. 2019.

[21] Kumaran E, Doum D, Keo V, Sokha L, Sam B, Chan V, et al., "Dengue knowledge, attitudes and practices and their impact on community-based vector control in rural Cambodia," PLoS Negl Trop Dis., vol. 12, no. 2, p. e0006268, 2018.

[22] Cronbach LJ, "Coefficient alpha and the internal structure of tests," Psychometrika, vol. 16, no. 3, pp. 297-334, 1951.

[23] Radhakrishna RB, "Tips for developing and testing questionnaires/instruments," Journal of extension, vol. 45, no. 1, pp. 1-4, 2007.

[24] Iacobucci D., Duhachek A., “Advancing alpha: Measuring reliability with confidence,” J Cons Psychol., vol. 13, pp. 478-487, 2003.

[25] Luskin RC, Bullock JG, 'Don't Know' means 'Don't Know: DK responses and the public's level of political knowledge," The Journal of Politics, vol. 73, no. 2, pp. 547-557, 2011.

[26] Wang H, "Treatment of "don't-know" responses in contingent valuation surveys: a random valuation model." Journal of Environmental Economics and Management, vol. 32, no. 2, pp. 219-232, 1997

[27] Panter-Brick, C., \& Fuentes, A., "Health, Risk, and Adversity," Berghahn Books, 2009.

[28] Lu SH, Tian BC, Kang XP, Zhang W., Meng XP, Zhang JB, Lo SK, "Public awareness of tuberculosis in China: a national survey of 69253 subjects," Int J Tuberc Lung Dis., 2009; vol. 13, no. 12, pp. 1493-1499, 2020.

[29] Johnson, E.J., Hariharan, S., "Public health awareness: knowledge, attitude and behaviour of the general public on health risks during the $\mathrm{H}_{1} \mathrm{~N}_{1}$ influenza pandemic," Journal. Public Health, vol. 25, no. 3, 333-337, 2017.

[30] Taylor, M., "Gender differences in health literacy about tuberculosis (TB) amongst south African high school students," The American Journal of Tropical Medicine and Hygiene, vol. 83S, no. 5, p. 201, 2010

[31] Guo, B., Cheng, H. Z., Xie, X. et al., "Investigation on the status of health knowledge level of medical students in a medical university," Medicine and Society, vol. 25, no. 7, pp. 10-12, 2012.

[32] Wellstead, P., "Information behaviour of Australian men experiencing stressful life events: the role of social networks and confidants," Information Research: an International Electronic Journal, vol. 16, no. 2, p. 474, 2011.

[33] Ebrahimi, M. M., Topchiyan, A., Farsad, N. E. and Noor M. M., "Knowledge and attitude about women's heart disease risk factors - obesity, CVD and its relationship Obesity index \& biochemical factors." University of Medical Sciences magazine of Tabriz. vol. 33, no. 2, pp. 7-12, 2011.

[34] Godfrey, Logan, "Social Media's Role in the Coronavirus Pandemic," 2020. [Online]. Available: https://www.business2community.com/social-media/social-medias-role-in-the-coronavirus-pandemic-02296280.

[35] Santiago, Jomell M. and David, Eden S., "The Use of Two Media of Instruction in Biology: A Quasi-Experimental Study," International Journal of Advanced Engineering, Management and Science, vol. 5, no. 2, pp. 111-115, 2019.

[36] Jedrzejewska, B., Kalinowski, P., and Stachowicz, A., "Knowledge of healthy behaviours among teenagers attending selected schools of the Lublin region," Annales Academiae Medicae Stetinensis, vol. 51, pp. 65-69, 2005. 